\title{
MENINGKATKAN DAYA SAING UMKM DALAM MENYONGSONG AEROCITY DI DESA KERTAJATI KABUPATEN MAJALENGKA
}

\author{
E. Mulya Syamsul, Hani Sri Mulyani, Rahayu Kusumadewi \\ Universitas Majalengka, Indonesia \\ mulya@unma.ac.id
}

\begin{abstract}
Majalengka Regency is one of the regencies in West Java Province that has the most dynamic changes, opportunities and challenges in the future in line with the many national programs in this region, such as West Java International Airport (BIJB) and the aerocity area, Jatigede Dam, Cisundawu toll road and others. This dynamic requires a touch of programs and policies so that the community and the region receive benefits from the changes that occur. Often local people become spectators or even become victims of changes that occur in their area. Therefore, in order for the community to be better prepared to face these changes, it is necessary to have a real effort in increasing the readiness of MSMEs to have competitiveness and adaptability to change and increase the number of new businesses in line with the flow of investment into Majalengka Regency.
\end{abstract}

Keywords: UMKM, Local Economic Potential, institutional strengthening, Competitiveness

\begin{abstract}
Abstrak
Kabupaten Majalengka merupakan salah satu kabupaten di Provinsi Jawa Barat yang memiliki dinamika perubahan, peluang dan tantangan yang paling besar dimasa yang akan datang seiring dengan banyaknya program nasional yang ada dikawasan ini, seperti Bandara Internasional Jawa Barat (BIJB) dan kawasan aerocity, Bendungan Jatigede, Jalan tol Cisundawu dan lain sebagainya. Dinamika tersebut membutuhkan sentuhan program dan kebijakan agar masyarakat serta daerah menerima manfaat dari perubahan yang terjadi. Seringkali masyarakat setempat menjadi penonton atau malah jadi korban dari perubahan yang terjadi di wilayahnya. Oleh karena itu agar masyarakat lebih siap menghadapi perubahan tersebut, maka perlu adanya upaya yang nyata dalam meningkatkan kesiapan UMKM agar memiliki daya saing dan daya adaptasi dengan perubahan dan meningkatknya jumlah usaha baru seiring dengan masuknya arus Investasi ke Kabupaten Majalengka
\end{abstract}

Kata Kunci: UMKM, Potensi Ekonimi Lokal, penguatan kelembagaan, Daya saing

\begin{tabular}{l|l|l} 
Submitted: $2020-06-28$ & Revised: $2020-07-26$ & Accepted: 2020-07-29
\end{tabular}

\section{Pendahuluan}

Usaha Mikro, Kecil dan Menengah (UMKM) memiliki peranan penting bagi perekonomian masyarakat suatu Negara termasuk Masyarakat Indonesia. Perhatian khusus pemerintah dibuktikan dengan adanya wadah khusus yang dibentuk oleh pemerintah dibawah kementrian Koperasi dan UMKM sebagai wujud perhatian pemerintah dalam menyangga perekonomian rakyat kecil yang akan mampu memberikan dampak secara langsung terhadap Masyarakat kecil dan menengah sebagai pelaku UMKM.

Bagi kehidupan masyarakat, UMKM memiliki beberapa peranan penting, diantaranya: Pertama, sebagai sarana mengentaskan masyarakat kecil dari jurang kemiskinan karena dengan adanya UMKM akan mampu menyerap banyak tenaga kerja, hal ini terbukti dari data yang dimiliki kementrian Koperasi dan UMKM, dimana lebih dari 52,2 juta unit UMKM mampu menyerap sekitar 101,7 juta orang di tahun 2011, angka 
tersebut meningkat menjadi 57,8 juta unit UMKM dengan jumlah tenaga kerja mencapai 114 juta orang (www.compasiana.com); kedua, UMKM merupakan sarana untuk meratakan perekonomian rakyat kecil, hal ini disebabkan karena UMKM memiliki lokasi diberbagai tempat termasuk di daerah-daerah yang jauh dari jangkauan perkembangan zaman. Indonesia merupakan Negara kepulauan yang tersebar dari sabang sampai merauke, sehingga dengan adanya UMKM tenaga kerja yang ada di daerah tidak perlu sulit untuk mencari lapangan pekerjaan ke kota; ketiga, UMKM mampu memberikan pasukan bagi Negara berupa devisa. Perkembanga UMKM yang sudah sangat maju sehingga mampu menjangkau pangsa pasar yang tidak hanya di dalam negeri tetapi juga pangsa pasar internasional sehingga mampu menghasilkan devisa Negara. Hal ini terbukti dari data yang dimiliki Kementrian Koperasi dan UMKM Tahun 2017 menunjukkan tingginya devisa Negara dari para pelaku UMKM yang angkanya mencapai Rp. 88,4 Milyar, angka ini mengalami peningkatan delapan kali lipat dibandingkan tahun 2019.

Kabupaten Majalengka merupakan salah satu kabupaten di Provinsi Jawa Barat yang memiliki dinamika perubahan, peluang dan tantangan yang paling besar dimasa yang akan datang seiring dengan banyaknya program nasional yang ada dikawasan ini, seperti Bandara Internasional Jawa Barat (BIJB) dan aerocity, Bendungan Jatigede, Jalan tol Cisundawu dan lain sebagainya. Dinamika tersebut membutuhkan sentuhan program dan kebijakan agar masyarakat serta daerah menerima manfaat dari perubahan yang terjadi.

Dampak dari hadirnya BIJB, tol trans Jawa dan mulai beroperasinya waduk jatigede serta program nasional dan regional, berpotensi merubah struktur dan kultur kehidupan masyarakat, khususnya pelaku UMKM. Dinamika perubahan sebagai akibat keberhasilan pembangunan tersebut akan mendorong pertumbuhan ekonomi di Majalengka sekaligus merubah kemapanan mata pencaharian yang selama ini telah terbentuk. Masyarakat Majalengka yang semula bermata pencaharian dari sektor pertanian beserta turunan-turunanya harus mampu menyesuaikan diri dengan mindset dan skill baru agar masyarakat siap menghadapi perubahan dan dampak dari kehadiran fasilitas ini yaitu berubahnya peruntukan lahan secara massif dan datangnya investasi serta tenaga kerja luar daerah yang berpeluang menggantikan posisi historis masyarakat Majalengka.

Seringkali masyarakat setempat menjadi penonton atau malah jadi korban dari perubahan yang terjadi di wilayahnya. Oleh karena itu agar masyarakat lebih siap menghadapi perubahan tersebut, maka perlu adanya upaya yang nyata dalam meningkatkan kesiapan UMKM agar memiliki daya saing dan daya adaptasi dengan perubahan dan meningkatknya jumlah usaha baru seiring dengan masuknya arus Investasi ke Kabupaten Majalengka

Untuk membangun UMKM agar memiliki kemampuan dan daya saing diperlukan program kemitraan Masyarakat (PKM) Universitas Majalengka yang bekerjasama dengan pemerintah Daerah Kabupaten Majalengka untuk melakukan kegiatan pembinaan yang didasarkan pada data UMKM yang memiliki validitas tinggi sehingga program penguatan UMKM dapat diselenggarakan sesuai dengan kondisi dan Kebuthan dari UMKM itu sendiri dalam menangkap peluang dan tantangan di Kabupaten Majalengka. 
Lokasi PKM akan di fokuskan pada wilayah yang berdampak secara serius dalam peta pengembangan wilayah perkotaan yaitu wilayah Kecamatan Kertajati Kabupaten Majalengka. Melihat pentingnya pengembangan ini, UMKM sebagai unsur strategis mempunyai peran yang sangat penting dalam menjawab seting wilayah tersebut sehingga UMKM dapat beradaptasi dan berpartisipasi aktif dalam memanfaatkan bonus pengembangan wilayah yang di kembangkan melalui dampak BIJB, Aerocity dan dampak lain yang mempengaruhinya.

\section{Metode}

Kunci keberlanjutan pengembangan klaster yaitu terciptanya kerjasama antara stakeholder dan efisiensi kolektif yang dapat dilakukan pada semua lini tahapan produksi mulai dari penyediaan input, produk, proses produksi, pemasaran dan distribusi hingga ke konsumen akhir. Jalinan kerjasama dalam lingkungan usaha klaster memberikan manfaat yang positif dengan menciptakan rantai nilai produksi yang saling menguntungkan (JICA, 2004). Selain itu sinergitas dari semua stakeholders yaitu bidang Academic, Bussines, Community, Government dan Media akan mempercepat pengembangan UMKM.

Sehubungan dengan konsep pengembangan UMKM tersebut yang tertuju pada peningkatan daya saing UMKM, maka diperlukan beberapa kegiatan dalam mencapai tujuan pengembangan tersebut secara sistematis. Berbagai kegiatan yang akan dilaksanakan dapat melibatkan kelompok UMKM, dinas terkait, penyuluh lapangan, akademisi serta koperasi dan lembaga lainnya yang terkait.

Tahapan kegiatan yang akan dilaksanakan melalui berbagai tahapan yaitu tahap pertama merupakan tahap persiapan, tahap perancangan dan implementasi sedangkan tahap selanjutnya yaitu rencana kegiatan pengoptimalan dalam pengembangan UMKM dalam meningkatkan daya saing UMKM. Secara lebih jelas dapat dirinci sebagai berikut:

1. Tahap persiapan

Pada tahap persiapan, terdapat kegiatan pengidentifikasian UMKM dan pemetaan UMKM ke dalam tingkatan UMKM sehingga program PKM ini mampu memberikan kontribusi yang tepat bagi setiap lininya . Hasil dari kegiatan ini akan dijadikan dasar dalam menyusun tahapan program yang akan dikembangkan.

2. Tahap pelaksanaan

Tahap pelaksanaan terdiri dari :

1. Penguatan kelembagaan

Secara rinci tahapan kegiatannya adalah:

(a) Peningkatan kesadaran dalam meningkatkan peran UMKM dalam menyongsong era pasar bebas dan masuknya investor dengan mudahnya akses sebagai dampak dari pembangunan BIJB, aerocity dan pembangunan jalan tol

(b) Peningkatan Kapasitas Organisasi melalui pelatihan SDM terkait pengembanganUMKM

2. Studi Kelayakan Usaha

Melakukan penilai kelayakan Usaha UMKM sehingga mampu membantu perancangan bussines plan dan menjadi fasilitator untuk akses permodalan

3. Inovasi bisnis 
(a) Memberikan pelatihan tentang inovasi produk sehingga UMKM memiliki keunggulan

(b) Membantu menemukan branding atas produk UMKM sehingga UMKM mampu bersaingan ditengah persaingan usaha

4. Membangun Jejaring

(a) Memberika pelatihan tentang Penguatan mata rantai pasokan dimulai dari pasokan bahan baku, efisiensi dan efektifitas proses produksi sampai pemasaran produk UMKM

(b) Membantu penentuan marketshare

\section{Hasil dan Pembahasan}

A. Pengembangan Wilayah Aerocity BIJB Kertajati

Pembangunan Bandara Internasional Jawa Barat (BIJB) yang terletak di Kertajati Kabupaten Majalengka telah banyak merubah tatanan kehidupan social kemasyarakatan warga masyarakat Desa Kertajati sebagai daerah penyangga utama BIJB. Fenti Jimika dalam Jurnalnya yang berjudul Dampak Pembangunan Bandara Kertajati terhadap Struktur Perekonomian Majalengka menggambarkan bahwa kehadiran BIJB sangat berdampak pada pertumbuhan ekonomi berdasarkan produk domestic bruto regional bruto (PDRB) Kabupaten Majaelngka, ekonomi Kabupaten Majalengka mampu tumbuh 6,81 persen sejak tahun 2013 sampai dengan 2017.

Lebih lanjut dalam Jurnal tersebut disampaikan bahwa, besaran pertumbuhan berhasil lebih tinggi disbanding dengan pertimbuhan ekonomi nasional sebesar 5,07 persen dan Jawa Barat 5,29 persen. Dari perkembangan tersebut maka sudah dipastikan kehadiran BIJB dapat dan mampu mendorong kegiatan peningkatan ekonomi wilayah hususnya Kabupaten Majaelnga.

Desa Kertajati merupakan wilayah penyangga utama kehadiran BIJB, pertumbuhan ekonomi Kabupaten Majalengka diatas pertumbuhan nasional dan Jawa Barat harus pula dirasakan oleh masyarakat Desa Kertajati, sejatinya petumbuhan itu tergantung pada berdayanya UMKM yang tumbuh di masyarakat. Desa Kertajati sebagai sub model aerocity harus dapat mampu memberikan dampak pada nilai pertumbuhan ekonomi masyarakat, masyarakat menjadi factor utama dalam pembangunan-pembangunan yang lainnya. 


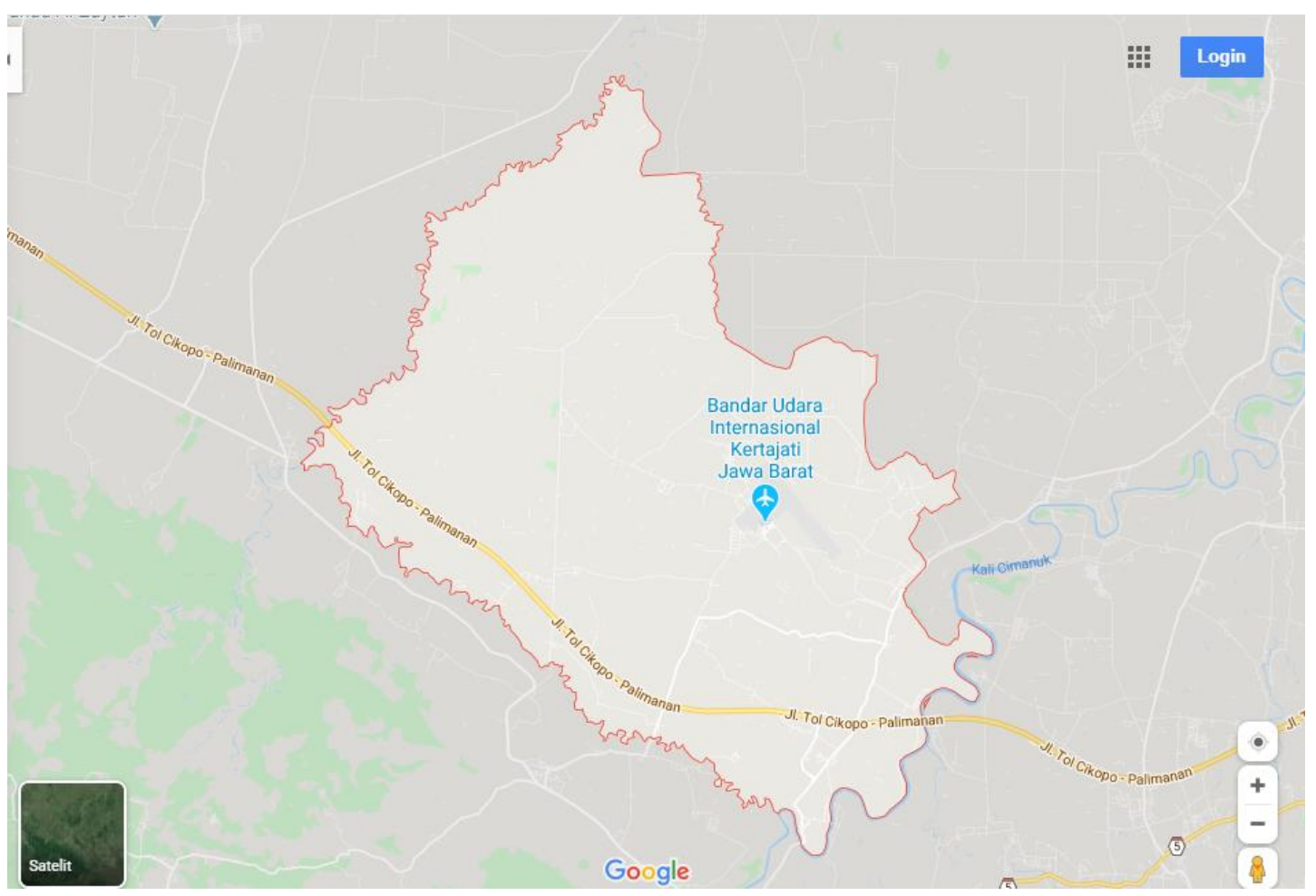

Gambar 1. Peta Wilayah Kertajati

Kawasan aerocity ini berkembang dalam koridor ekonomi yang menghubungkan koridor metropolitan Bandung Raya dengan Cirebon Raya juga memiliki potensi untuk mengurangi disparitas pembangunan yang hanya terkonsentrasi di wilayah Bogor, Depok, Bekasi, Karawang dan Purwakarta (Bodebekapur) (Tri Tjahjono, dkk: 2017).

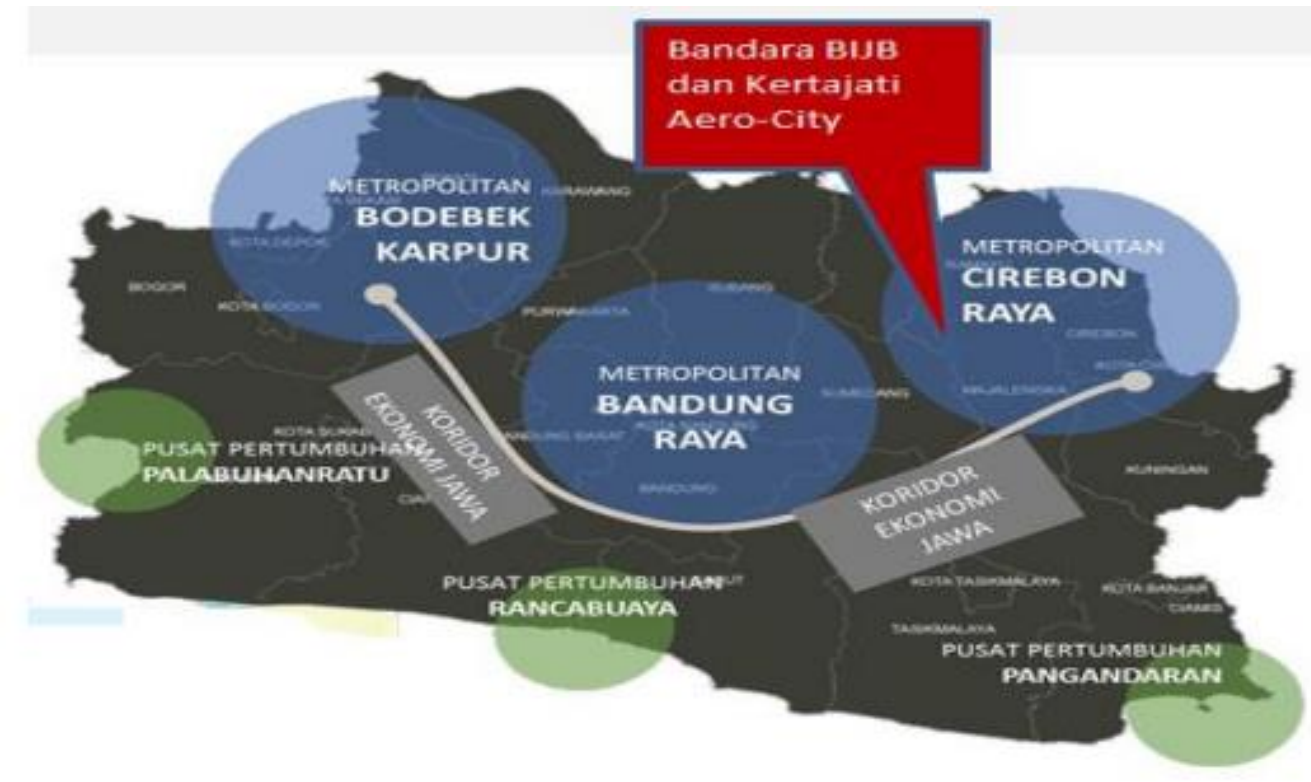

Gambar 2. Wilayah Pertumbuhan di Provinsi Jawa Barat dan Lokasi Bandara Internasional Jawa Barat (Tri Tjahjono, dkk: 2017). 

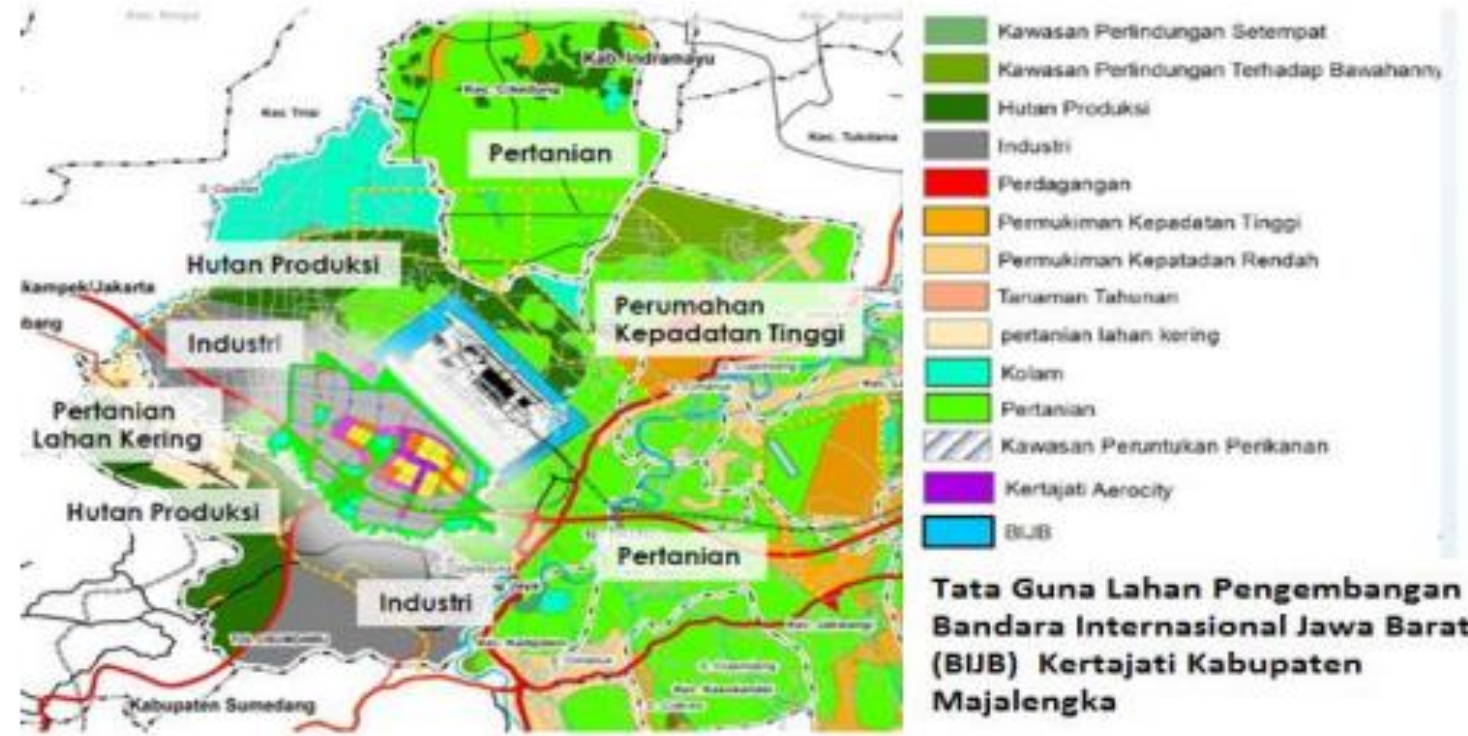

Gambar 3. Tata Guna Pengembangan BIJB Kertajati (Tri Tjahjono, dkk: 2017).

B. Peta UMKM Desa Kertajati Kecamatan Kertajati Kabupaten Majalengka

Potensi UMKM masyarakat Desa Kertajati tersebar di beberapa blok yaitu Blok Senin, Blok Selasa, Blok Rabu dan Blok Ahad dengan hasil peroduksi yang bermacammacam, mulai dari kuliner, toko kelontongan, feshen dan kerajinan. Ketersebaran ini menunjukan masyarakat Desa Kertajati mempunyai nilai produktifitas yang tinggi dan mempunyai kesiapan terhadap perubahan wilayah seiring dengan kemajuan zamannya. Berikut gambaran peta UMKM Desa Kertajati.

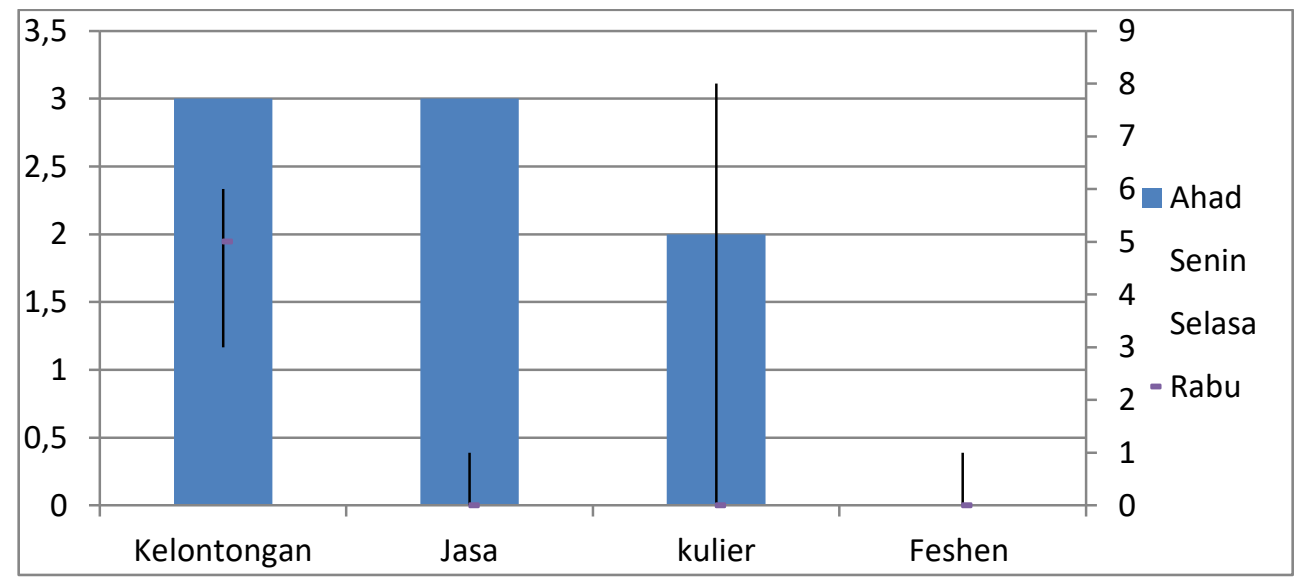

Gambar 4. Diagram pemetaan UMKM berdasarkan wilayah

Dari gambaran potensi sebagaimana peta diagram diatas menunjukan bahwa bidang kelontongan dan jasa menjadi kegiatan yang paling banyak di pilih oleh masyarakat dalam berkegiatan di bidang UMKM.

Data tersebut di oleh dari penyebaran formulir data profil UMKM yang telah di tetapkan melalui formulir Jabar Juara, formulir ini dilakukan untuk menyamakan hasil yang didapat dari data-data yang disi oleh masyarakat terhadap kegiatan usahanya. 
Adapun nilai asset yang mereka miliki dari usaha yang dijalankannya masuk pada katagori Usaha Mikro dan Usaha Kecil Menengah, dengan nilai aseet berkisar di angka Rp. 100.000.000 sampai pada Rp. 300.000.000. berikut persentasi nilai asset dari setiap UMKM di Desa Kertajati.

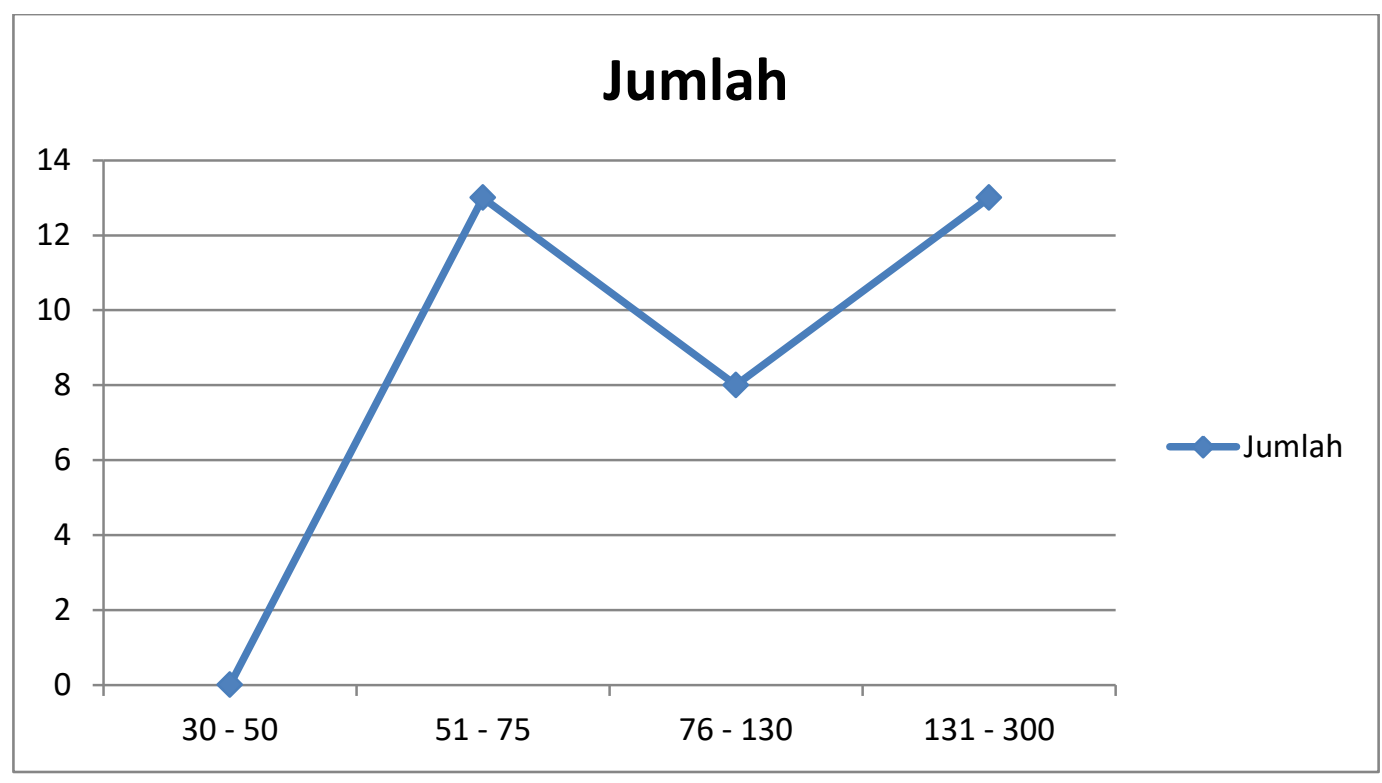

Gambar 5. Diagram Persentasi Asset UMKM

C. Penguatan Kelembagaan UMKM

Pola pengabdian yang dilakukan adalah memperkuat kelembagaan UMKM sebagaimana data yang telah diuarai dalam peta UMKM Desa Kertajati, nguatan kelembagaan ini penting dan menjadi prasyarat utama dalam menghadapi era perdagangan bebas.

Hal yang dilakukan dalam pengauatn UMKM adalah dengan terlebih dahulu mengidentifikasi UMKM sebagaimana terambar pada table I, dari data tersebut diidentfikasi berapa yang telah mempunyai izin atau belum, izin tersebut terdiri dari SKI, IUMK, SIUP, SITU, TDP, NPWP dan lainnya. Berikut data hasil identifikasi kelembagaan.

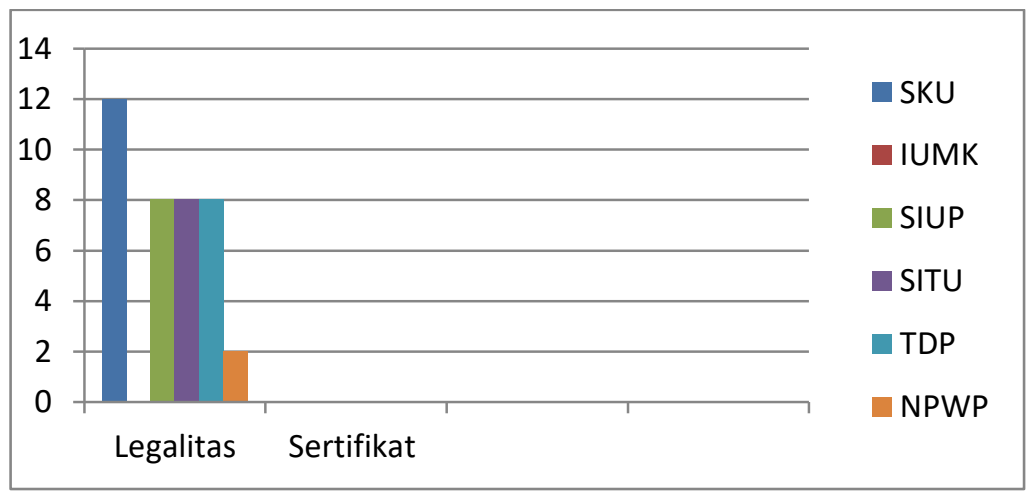

Gambar 6. Diagram Penguatan Izin UMKM 
Dari identifikasi tersebut, perlu terus dilakukan pola penguatan kelembagaan baik melalui pelatihan, temu bisnis dan lain sebagainya sebagaimana telah dilakukan dalam pengabdian ini;

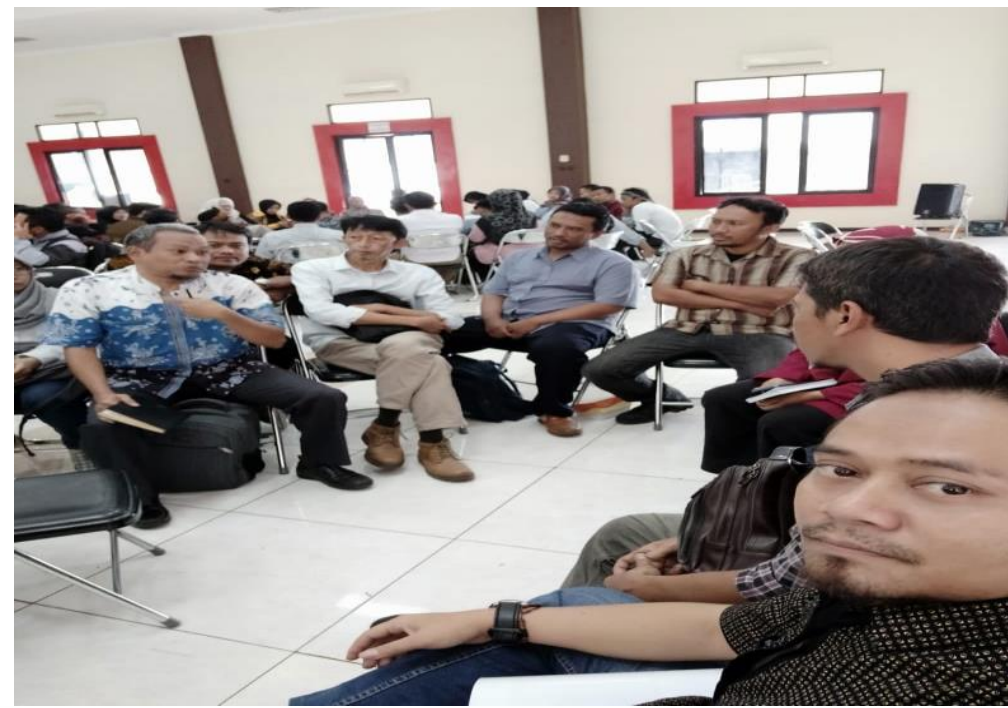

Gambar 7. Kegiatan Penguatan Kelembagaan UMKM Desa Kertajati

D. Kelayakan Usaha

Upaya yang dilakukan dalam mempersiapkan UMKM di era baru pada wilayah aerocity adalah melakukan pemahaman dengan pentingnya membangun usaha yang layak dan teratur. Kegiatan ini dilakukan dengan cara melakukan kegiatan mentoring per blok yang terdri dari 10 UMKM. Hal ini dilakukan agar dapat pemahaman yang maksimal terhadap mean set usaha yang dilakukannya, berikut catatan sebelum pemahaman dan setelah pemahaman.

Tabel 1. Hasil evaluasi kegiatan

\begin{tabular}{cllrl}
\hline No & Materi Mentor & \multicolumn{2}{c}{ Sebelum Pemahaman } & \multicolumn{2}{c}{ Setelah Pemahaman } \\
\hline 1 & $\begin{array}{l}\text { Membangun } \\
\text { Usaha ditengah } \\
\text { persaingan }\end{array}$ & Mereka & $\begin{array}{l}\text { tidak } \\
\text { mempedulikan bagaimana }\end{array}$ & Terdapat cukup perubahan, \\
usaha & terlihat dari respon mereka & terhadap keikut sertaan dalam \\
2 & $\begin{array}{l}\text { Pentingnya } \\
\text { upaya teknologi }\end{array}$ & Tidak terpikirkan oleh & menyimak materi. & Mereka mempunyai target \\
& mereka hal teknologi & $\begin{array}{l}\text { pemasaran melalui online } \\
\text { walaupun harus belajar lebih } \\
\end{array}$ & & lanjut \\
\hline
\end{tabular}

Dua meteri itu sengaja dipilih untuk melihat sejauh mana kebiasaan mereka dan bagaimana mereka mempersiapkan diri dalam menghadapi era baru di wilayah aerocity ini. Dengan hasil demikian, para pelaku UMKM merasa optimis dalam menghadapi era baru itu. 


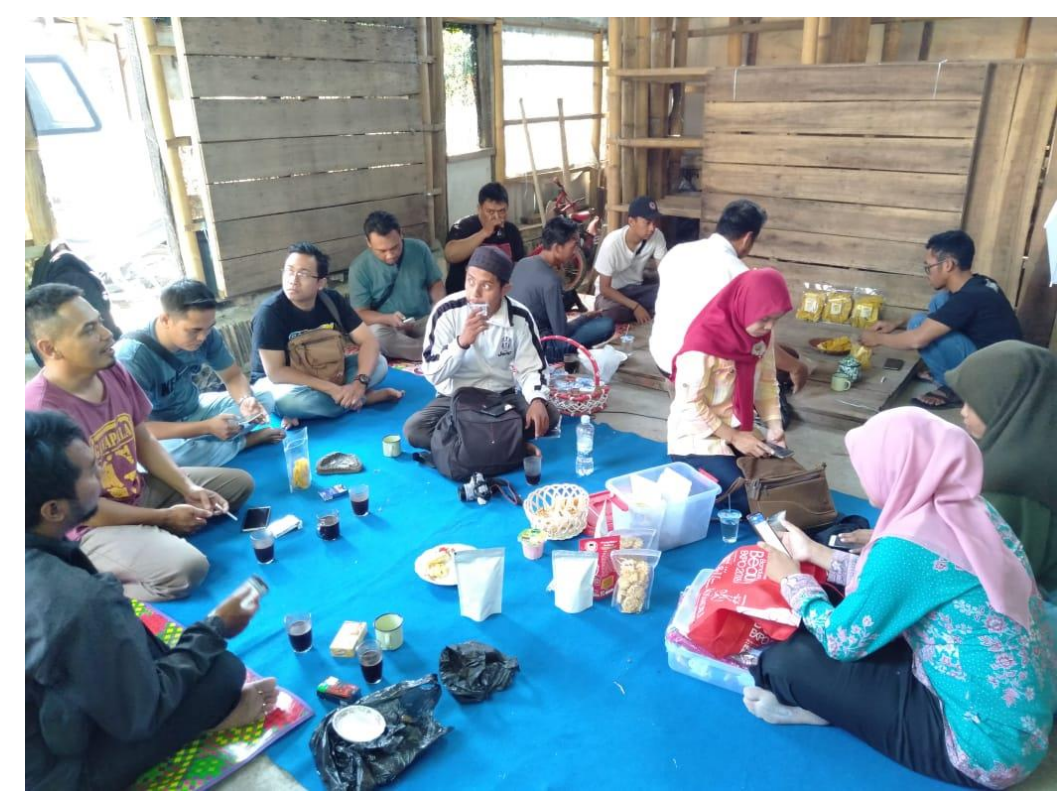

Gambar 8. Kegiatan mentor penguatan kelayakan usaha

E. Inovasi Bisnis

Kegiatan selanjutnya dalam pengabdian ini adalah melakukan upaya pemahaman pentingnya Inovasi Bisnis yang telah berjalan, pemahaman ini dilakukan melalui workshof pelatihan kemasan yang dikerjasamakan dengan Dinas Koperasi UKM Kabupaten Majalengka, tidak semua masyarakat dapat mengikuti tetapi beberapa UKM yang dipandang mempunyai produk layak untuk dikembangkan dan diberi sentuhan inovasi, baik dalam bentuk kemasan dan yang lainnya.

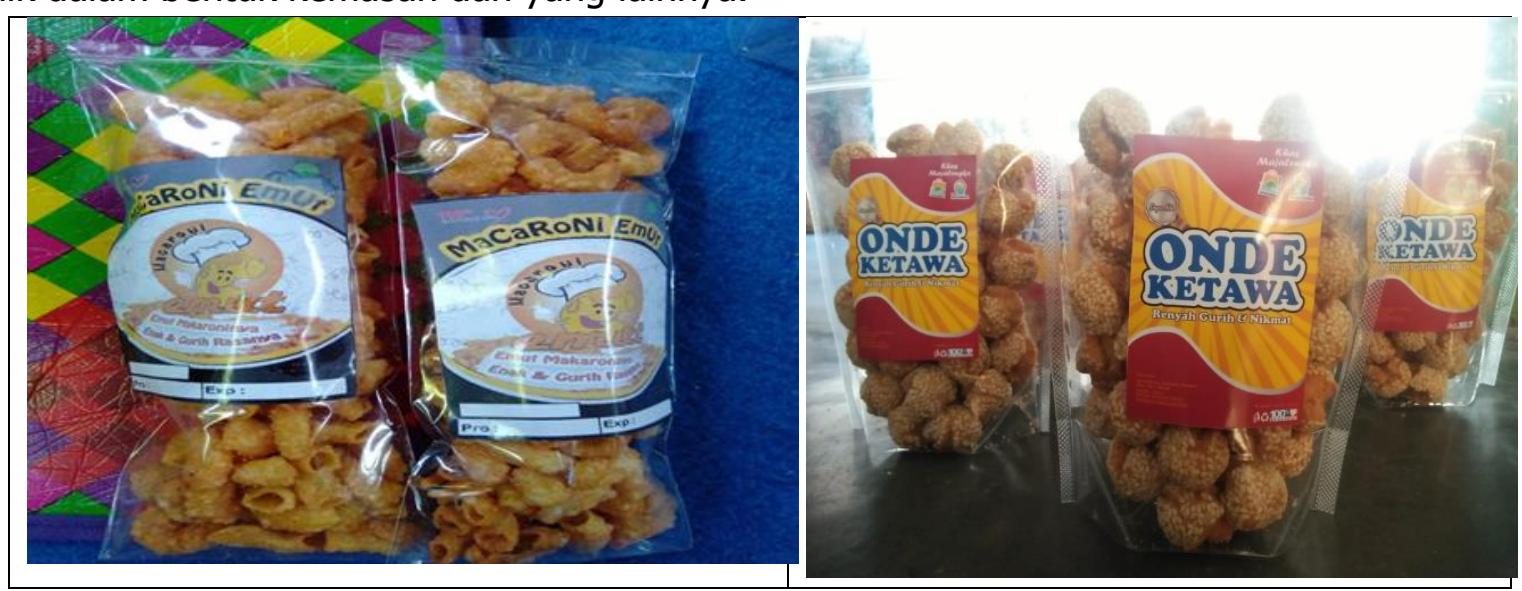

Gambar 9. Contoh inovasi kemasan produk 


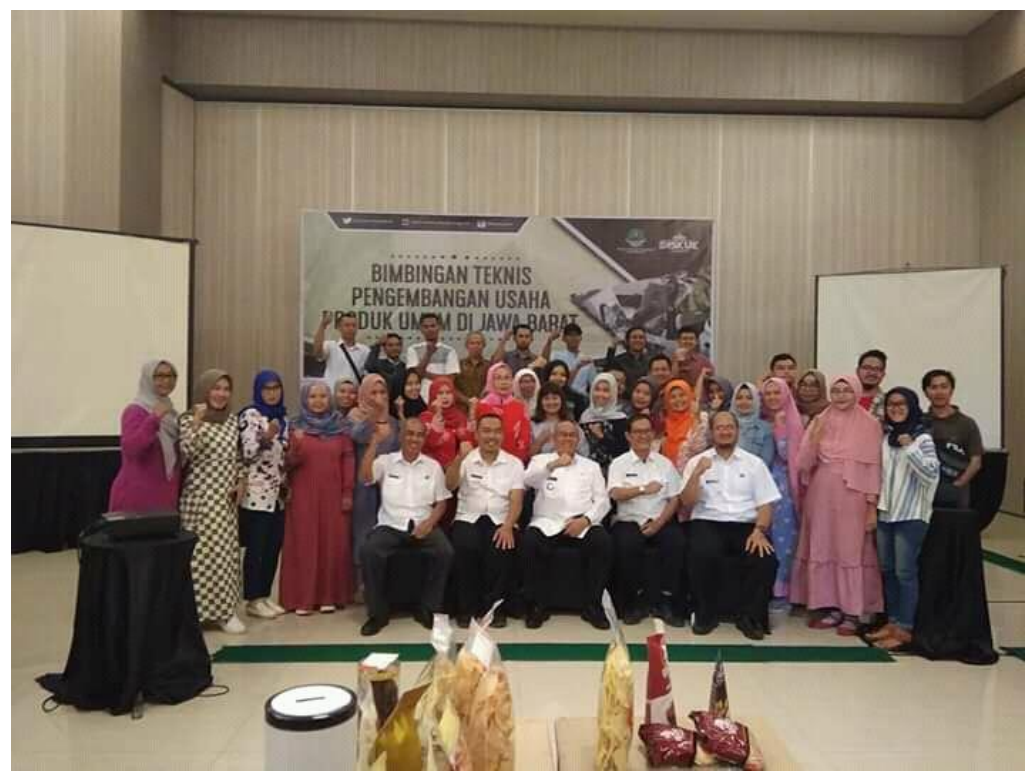

Gambar 10. Foto kegiatan Inovasi Bisnis kerjasama Dinas Koperasi UKM

F. Membangun jejaring

Kegiatan terakhir dalam siklus pengabdian adalah membangun jejaring UMKM dengan lembaga-lembaga keuangan, ini dilakukan agar UMKM yang telah mempunyai kesiapan untuk maju mendapatkan suntikan dana permodalan dari pihak ke tiga khususnya perbankan.

Workshof penguatan kelembagaan dan Inovasi bisnis yang dilaksanakan juga menhadirkan stekholder bidang perbankan, kami mencoba memberikan edukasi pada mereka agar UMKM yang telah mendapatkan kesiapan menjadi mitra perbankan sebagai penyokong modal. Selain itu perbankan menjadi pembina langsung dalam peningkatan kapasitas UMKM.

\section{Kesimpulan}

Berdasarkan hasil kegiatan pengabdian ini dapat disimpulkasn sebagai berikut:

1. Peningkatan UMKM masyarakat Desa Kertajati, Kecamatan Kertajati Kabupaten Majalengka perlu terus ditingkatkan baik melalui pola kerjasama Dinas maupun mandiri, terutama pada wilayah-wilayah yang menjadi agenda perkotaan (aerocity).

2. Kesiapan UMKM Desa Kertajati dalam menghadapi aerocity belum tergambar dengan jelas, hal ini upaya lain selain pengabdian yang dilakukan secara mandiri dan atau oleh komunitas lain perlu di galakan agar tercipta pemahaman dan penyadaran yang ada ditengah-tengah masyarakat.

3. Beberapa produk yang ditemudi di UMKM Desa Kertajati memiliki keunikan dan keunggulan, dan ini merupakan modal utama dalam menghadapi situasi gelobal dalam seting perkotaan.

\section{Daftar Pustaka}


Fenty Jimika, (2019), Dampak Pembangunan Bandara Kertajati Terhadap Struktur Perekonomian Majalengka, Maro, Jurnal Ekonomi Syariah dan Bisnis, Vol. 3. No. 1, Mei 2019

JICA. (2004). Final Report of The Study on strengthening Capacity of SME Cluster in Indonesia, Japan International Cluster Agency.

Porter ME, (2000). Location, Competition and Economic Development: Local Cluster in A Global Economy, Economic Development Quarterly Vol 14 No.1

Rencana pembangunan Jangka Menengah Daerah kabupaten Majalengka, 2018-2023. Majalengka

Ropke. Jochen (1991), Cooperativ Enterpreneurship, Marburg.

Soetrisno, Loekman (1995). Membangun Ekonomi Rakyat Melalui Kemitraan: Suatu Tinjauan Sosiologis, Makalah dalam Diskusi Ekonomi Kerakyatan, Yogyakarta.

Tri Tjahjono, Dkk, (2017). Bandara Udara Internasional Jawa Barat (BIJB) dan potensi Kertajati Sebagai Aerocity, WARTA ARDHIA, Jurnal Perhubungan Udara. 